\title{
SZLACHTA WOJEWÓDZTWA KIJOWSKIEGO WOBEC PROBLEMÓW SĄDOWNICTWA W DRUGIEJ POŁOWIE XVII WIEKU
}

\author{
Jarosław Stolicki (D) http://orcid.org/0000-0002-8357-8101 \\ Uniwersytet Jagielloński w Krakowie
}

\author{
ABSTRACT \\ NOBILITY OF THE KIEVAN PALATINATE AND THE PROBLEMS \\ OF JUDICIAL ORGANIZATION IN THE SECOND HALF OF THE \\ $17^{\text {TH }}$ CENTURY
}

The Polish-Lithuanian Commonwealth's nobility attached great importance to the proper functioning of the judicial system, and the administrative issues of the justice system were among the principal matters discussed in the dietines. They were of particular importance to the Kievan nobility during their exile in the second half of the $17^{\text {th }}$ century. The article discusses the statutes aimed at providing them relief during that period. The one of major importance was the act of 1683 that established county courts in the Owrucz and Żytomierz counties. The latter was carried into execution only in 1701 . The same statute also prescribed the duties of the castle officials responsible for holding courts in Żytomierz and Owrucz. The article also discusses the issues of judicial administration in the Kievan palatinate and the proposals for the judicial reform raised by the dietines (especially between 1661 and 1667), which were only carried out in 1684, when the Kievan and Owrucz sheriffs were sworn in.

Keywords: nobility, Kievan palatinate, statutes, dietines, county and castle courts, assizes.

Słowa kluczowe: szlachta, województwo kijowskie, konstytucje, sejmiki, sądy grodzkie i ziemskie, roczki.

Udział szlachty w wymiarze sprawiedliwości przyczynił się do powstania sejmików. Działały one jako organy sądowe, a ich uchwały dotyczyły rozmaitych sfer prawa. Wybierały też kandydatów na urzędy ziemskie. W latach 1572-1578 nastąpił wyraźny wzrost znaczenia zgromadzeń szlacheckich, także w tym zakresie. Przejawiał się on w sądach kapturowych i w wyborach deputatów do trybunału. Problemami 
funkcjonowania sądownictwa szlachta zajmowała się właściwie podczas każdego rodzaju sejmików. Narzekania na niedomagania sądów (z reguły trybunału) oraz postulaty ich naprawy zajmowały dużo miejsca w instrukcjach dla posłów na sejmy. Ze specyficzną sytuacją spotykamy się w wypadku sejmików na wygnaniu. Egzulanci ukrainni odbywali zgromadzenia we Włodzimierzu, a w tamtejszym grodzie oblatowali dokumenty. Warto więc prześledzić, w jaki sposób fakt wygnania wpłynął na funkcjonowanie ich sądów.

Materiałów dotyczących sądów województw bracławskiego i czernihowskiego właściwie nie ma, bo one nie działały. Szlachta kijowska była w innej sytuacji, ponieważ w okresie wygnania czasem posiadała własne sądy. Musiała w związku z tym zadbać o ich prawidłowe działanie. Trudy codziennego życia skłaniały szlachtę również do domagania się zmian w zakresie sądownictwa. W artykule omówiono te kwestie, które były konsekwencją funkcjonowania szlachty tegoż województwa na wygnaniu. Przedstawiono konstytucje dotyczące spraw sądowych egzulantów. One częściowo dotyczyły także pozostałych województw ukrainnych. Ponadto zwrócono uwagę na postulaty zmian w funkcjonowaniu sądów województwa, jakie zgłaszali Kijowianie, i ich realizację. Dla województwa kijowskiego zachowało się niemało źródeł, na podstawie których można ten problem, przynajmniej częściowo, wyjaśnić. Nie analizowano natomiast tego, jaki był stosunek sejmiku do funkcjonowania Trybunału Koronnego ${ }^{1}$. Pominięto też problemy związane z faktem, że urzędy sądowe nie były obsadzone. Ten aspekt $\mathrm{w}$ większym stopniu jest związany z sejmikami elekcyjnymi. O ile problematyka sądów, ksiąg oraz kancelarii grodzkich była już przedmiotem badań, o tyle historycy polscy nie zajmowali się dotychczas województwem kijowskim ${ }^{2}$. W niniejszym artykule przedstawiono tylko zagadnienie funkcjonowania sądów. Kwestia ksiąg w tym czasie zasługuje na osobne studium, a na temat personelu kancelarii można podać więcej ustaleń, badając ten aspekt w dłuższym okresie.

Województwo kijowskie po unii lubelskiej stanowiło jeden powiat ziemski i grodzki z siedzibą w stolicy. Sąd ziemski miał zbierać się początkowo według alternaty w Kijowie, Żytomierzu i Owruczu, ale od roku 1607 już tylko w Kijowie. Roczki grodzkie odbywały się w Kijowie. Ze względu na duży obszar województwa już

${ }^{1}$ Problem ten był już przedmiotem badań, zob. W. Mais e1, Trybunat Koronny w świetle laudów sejmikowych i konstytucji sejmowych, „Czasopismo Prawno-Historyczne” 1982, t. XXXIV, z. 2, s. 73-109; S. Ochmann-Staniszewska, Uwagi o politycznej roli Trybunatu Koronnego w XVII w. [w:] Między Wschodem a Zachodem. Rzeczpospolita XVI-XVIII w., Warszawa 1993, s. 103-110; W. Be dnaruk, Sejmiki deputackie województw poludniowo-wschodnich Rzeczypospolitej od XVI do XVIII wieku [w:] Wielokulturowość polskiego pogranicza. Ludzie - idee - prawo, red. A. Lityński, P. Fiedorczyk, Białystok 2003, s. 259-267.

${ }^{2}$ Problematykę sądownictwa województwa kijowskiego przedstawił skrótowo М. Крикун, Повітовий поділ Київського воєводства в останній третині XVI-XVIII cm. [w:] Iсторикогеографічні дослідження на Украӥні. Збірник наукових праиь, Киев 1992, s. 68-84. Na kwestię sądów w czasie wygnania zwróciłem uwagę w artykule: Problemy szlachty kijowskiej w drugiej połowie XVII w. [w:] Studia i materiaty z historii nowożytnej i najnowszej Europy Środkowo-Wschodniej, t. 1: Na styku epok. Ziemie poludniowo-wschodniej Rzeczypospolitej od XVII do poczattku XIX wieku, red. T. Kargol, W. Michałowski, Kraków-Kijów 2020, s. 49-68. Ponieważ jednak był to jeden z kilku przedstawionych tam problemów, został on raczej postawiony, niż wyjaśniony. 
od przeprowadzenia reform w 1566 roku w Żytomierzu oraz w Owruczu funkcjonowały urzędy grodzkie, których zadaniem było prowadzenie $\mathrm{ksiąg}^{3}$. Na początku powstania Chmielnickiego miasta te zostały zajęte przez Kozaków. Większość szlachty uciekła, a jesienią 1648 roku zasięg powstania jeszcze się rozszerzył, obejmując nie tylko Ukrainę i Wołyń, ale i tereny województwa ruskiego. Spowodowało to duże problemy obywateli tych ziem. Szlachta Rzeczypospolitej starała się przynajmniej częściowo udzielić im pomocy. Już na sejmie koronacyjnym uchwalono konstytucję, na podstawie której obywatele terenów zniszczonych przez nieprzyjaciela uzyskali prawo do odłożenia w trybunale spraw, w których występowali ${ }^{4}$. Konstytucja ta została przedłużona podczas kolejnego sejmu. Wówczas zawieszono też egzekucje dekretów, które zapadły w trybunale, a dotyczyły kilku problemów istotnych dla wygnańców, do decyzji przyszłego sejmu.

Pierwszy postulat w zakresie sądownictwa przedstawiony przez szlachtę kijowską podczas wygnania dotyczył konieczności powołania sądów skarbowych. Zgłoszony został na sejmiku po koronacji 15 marca 1649 roku, ponieważ uchwalono wówczas podatki w celu powołania wojsk powiatowych. Zebrani postulowali, aby po mianowaniu i wjeździe nowego wojewody (ten urząd wówczas wakował) rozpoczął on sprawowanie sądów grodzkich, nawet wówczas, gdy ich normalna kadencja nie przypadała „dla samych skarbowych spraw”. Jeżeliby roczki nie mogły się odbyć w Kijowie, to naznaczano ich przeprowadzenie w grodach województwa wołyńskiego - w tym, gdzie najszybciej przypadała ich kadencja. Sądy skarbowe miały się zacząć tydzień po terminie oddania asygnacji przez komisarzy. Mieli im podlegać poborcy (także ci, którzy nie oddali dawnych retent), wspomniani komisarze do rozliczeń oraz rotmistrzowie. W przyszłości jednak, podczas wybierania kolejnych ćwierci, sprawy skarbowe miały być sądzone w Kijowie co dwa tygodnie.

Wkrótce potem wojewodą kijowskim został mianowany Adam Kisiel, który powołał pisarza grodzkiego. Adam Czarnołuski złożył przysięgę w obecności zebranych na sejmiku relacyjnym 7 marca 1650 roku$^{6}$. Wśród nich byli najważniejsi

${ }^{3}$ O reformie administracyjnej na Litwie za Zygmunta Augusta zob. A. Rachuba, Wielkie Księstwo Litewskie w systemie parlamentarnym Rzeczypospolitej w latach 1569-1763, Warszawa 2002, rozdz. II; Urzędnicy województw kijowskiego i czernihowskiego XV-XVIII wieku. Spisy, oprac. E. Jan as, W. Kłaczew ski, Kórnik 2002, 8-9; М. Крикун, op. cit., s. 74-76. Konstytucja z 1607 r. „O Rokach Ziemskich Kiiowskich”, Volumina Legum, Warszawa 1980, t. II, s. 447 [dalej: VL] została uchwalona na prośbę Kijowian, a potwierdzona na kolejnym sejmie. Ibidem, s. 470. Postulując odbywanie sądów ziemskich tylko w stolicy województwa, szlachta kierowała się troską o bezpieczeństwo ksiąg, które w trakcie przewożenia ulegały zniszczeniu.

${ }^{4}$ „Securitas honorum et bonorum obywatelów, Kiowskiego, Wołyńskiego, Podolskiego, Bracławskiego, y Czerniechowskiego, Woiewodztw; Ziemie Halickiey, także Krasnostawskiego, y Latyczowskiego Powiatow”, VL, t. IV, s. 123-124; „Reassumptio konstytucyi Seymu przeszłego de securitate honorum et bonorum Woiewodztw, Ziemi, y Powiatow pewnych", ibidem, s. 132.

${ }_{5}^{5}$ Архив Юго-западной России, издаваемый временной комиссией для разбора древних актов, состоящей при Киевском, Подольском и Волынском генерал-губернаторе [dalej: Archiv], cz. 2, t. I: Постановления дворянских провинциальных сеймов, в Югозападной России, Киев 1861, s. 349-361 (cyt. fragment s. 356).

${ }^{6}$ Центральний державний історичний архів України, Київ [Centralne Państwowe Archiwum Historyczne Ukrainy w Kijowie, dalej: CPAHUK], fond 11, ks. 13, Iurament wykonany przez jm. pana 
urzędnicy i metropolita prawosławny Sylwester Kossow. Sejmik ten odbył się już w Żytomierzu, gdzie wznowiono prowadzenie ksiąg. W źródłach brak jednak innych informacji dotyczących nie tylko sądów grodzkich w Kijowie, ale w ogóle funkcjonowania tamtejszego grodu. Z niektórych źródeł wynika, że różne dokumenty miały być oblatowane w Owruczu i Żytomierzu, nie ma zaś informacji o Kijowie. Nie wiadomo więc, czy w tym czasie odbywały się tam sądy. Wiemy jedynie, że w mieście przebywał wojewoda Kisiel, który miał zalecone przez króla troskę o poprawne relacje z Kozakami.

Druga kwestia podjęta podczas sejmiku z 15 marca 1649 roku dotyczyła powołania sądów ziemskich i grodzkich we wszystkich powiatach. Została ona przedstawiona, ponieważ obywatele domagali się rzetelnej kontroli w zakresie wybierania oraz rozliczenia podatków. Konieczność dokonania rozliczeń skarbowych leżała więc u źródeł przeprowadzenia większej zmiany. Szlachta argumentowała, że obywatele obszernego województwa, które „iedno tylko ziemstwo maiąc, ieden gród w Kiiowie" narażeni są na niedogodności. Zobowiązała się nawet, że do czasu uchwalenia stosownej konstytucji wstrzyma się z elekcjami wakujących urzędów pisarza i podsędka. W instrukcji danej posłom na sejm z 7 listopada 1650 roku Kijowianie ponowili ten postulat. Domagali się, ,aby roki ziemskie nie tylko w Kijowie, ale też w Żytomirzu i w Owruczu rządzone były [...] według porządku woiewodztwa Wołyńskiego, aby troiacy byli urzędnicy" ". Roki te w każdym zwyczajowym terminie miały się odbywać w innym mieście.

W kolejnej instrukcji, z 15 grudnia 1651 roku, ziemianie kijowscy zwrócili uwagę, że przyczyną większości ich problemów jest wakowanie urzędów sądowych, ale i skarżyli się na kłopoty z dojazdem do Kijowa. Było to w okresie zaostrzenia konfliktów, które doprowadziły wkrótce do wznowienia walk. Mieli też ponownie zalecone: „Starać się mają, aby ad instar woj wołyńskiego troie ziemstwa y trzy grody byli, w grodach zaś i ziemstwach aby, ad instar koronnych solaria brano"8. Apelowali również o uproszczenie procesów dotyczących poddanych, ,aby na roczkach, gdziekolwiek wprzód przypadną, lub w Kijowie, lub w Żytomierzu, lub w Owruczu sine ullis appellationibus, za pierwszym pozwem, wydawani byli”.

W latach 1652-1658 województwo kijowskie było opanowane przez Kozaków. Szlachta ukrainna odbywała sejmiki we Włodzimierzu i korzystała z tamtejszego grodu. Najpilniejsze dla niej kwestie regulowała konstytucja z 1654 roku. Uchwalając

Czarnołuskiego, k. 85v-86. Marszałek sejmiku podał do oblaty dnia 7 III 1650 r. ,iurament od ur. jm. pana Adama Ciołka Czarnołuskiego na urząd pisarstwa grodzkiego kijowskiego na sejmiku relacyjnym dnia dzisiejszego przy obecności ichm. panów obywatelów województwa kijowskiego i czernihowskiego wykonany [...]. ur. jm. pan Adam Ciołek Czarnołuski przez jw. jm. pana Adama z Brusiłowa Kisiela, wojewodę i generała ziem kijowskich [...] na urząd pisarstwa grodzkiego kij. podany. Przychylając się do prawa pospolitego, za wydaniem sobie roty iuramentu przez wielm. jm. pana Krzysztofa Tyszkiewicza [...] marszałka na ten czas koła rycerskiego, za spólną zgodą wszystkich ichm. panów dygnitarzów, ziemian i obywatelów".

${ }^{7}$ CPAHUK, fond 11, ks. 13, k. 596v-599v., toż Archiv, cz. 3, t. IV: Акты относящиеся к эпохе Богдана Хмельницкаго, Киев 1914, s. 523-530 (cyt. fragment na s. 526); Archiv, cz. 2, t. I, s. 356.

${ }^{8}$ Archiv, cz. 2, t. I, s. 414-425 (cyt. fragment na s. 420). 
ją, posłowie uwzględnili zniszczenie ksiąg, w związku z tym odnieśli się do kwestii rozstrzygania sporów dotyczących wywodów szlachectwa oraz majątkowych ${ }^{9}$.

Sytuacja zmieniła się po zawarciu ugody hadziackiej. Konieczne stało się dostosowanie do jej postanowień stosunków panujących na Ukrainie, a zwłaszcza położenia szlachty. Problemy te miały uregulować konstytucje z 1659 roku, z których na szczególną uwagę zasługuje „Seymiki y Elekcye Woiewodztw Ukrainnych”"10. Przewidywała ona przeprowadzenie rozgraniczenia ziem wchodzących w skład województwa. Powołano komisarzy, wśród których było też dwu pułkowników kozackich. Ich zadaniem było uzgodnienie kwestii związanych z rozgraniczeniem z podkomorzym kijowskim. Najważniejszym postanowieniem tej konstytucji dla omawianego problemu było powołanie sądów grodzkich w Owruczu i Żytomierzu. Po rozgraniczeniu starostowie żytomierski i owrucki (z urzędnikami) mieli złożyć przysięgę podczas pierwszych roków i przystąpić do sądzenia spraw obywateli w swoich grodach. Wojewoda kijowski powinien jak dotychczas sądzić sprawy obywateli ziemi kijowskiej. Sejmiki miały się dalej odbywać we Włodzimierzu, ponieważ tereny województwa kijowskiego były opanowane przez wojska moskiewskie. Postanowiono również, aby „Wszystkich spraw konserwaty obywatelom Woiewodztwa Kiiowskiego na teraźnieyszym Trybunale Lubelskim” zostały odłożone „ad feliciora tempora”"

Ukraina prawobrzeżna wróciła pod panowanie polskie w wyniku zwycięstw odniesionych w następnym roku. Sytuacja na Prawobrzeżu na tyle się unormowała, że w Żytomierzu 28 marca 1661 roku odbył się sejmik przedsejmowy. Instrukcja dana posłom na sejm została jednak oblatowana we Włodzimierzu, ,ponieważ gród Żytomirski ad praesens vacat"12.

Sejm z 1661 roku odbył się po zakończeniu potopu i odzyskaniu większości terenów wcześniej opanowanych przez Moskwę. Głównym celem pary królewskiej podczas obrad było przeprowadzenie elekcji vivente rege, ale sejm miał także uregulować różne sprawy utrudniające szlachcie $\mathrm{z}$ wielu ziem codzienne funkcjonowanie zwłaszcza w zakresie sądownictwa. Jedna z konstytucji dotyczyła konieczności zrewidowania stanu ksiąg, które uległy zniszczeniu w czasie działań wojennych ${ }^{13}$. $\mathrm{W}$ innej potwierdzono stare prawa zapewniające ochronę prawną posiadłościom szlacheckim na Wołyniu i Ukrainie (m.in. konstytucję z 1654 r.). Potwierdzono również bezpieczeństwo tych dóbr od przechodów i stancji wojskowych oraz wzięto w obronę egzulantów poszkodowanych w wyniku zagubienia aktów oraz tych,

9 "Securitas honorum et bonorum Woiewodztwa Kiiowskiego, Bracławskiego, y Czerniechowskiego", VL, t. IV, s. 207-208.

${ }^{10}$ Ibidem, s. 296.

11 „Conservati Woiewodztwa Kiiowskiego”, ibidem.

12 Archiv, cz. 2, t. II: Акты для истории провинииальных сеймиков Юго-Западного края во второй половине XVII века, Киев 1888, s. 119.

${ }^{13}$ „Securitas bonorum, et honorum, Woiewodztw, Kiiowskiego, Bracławskiego, Wołyńskiego, y Czerniechowskiego", VL, t. IV, s. 338. Postulat reasumpcji tej konstytucji zgłaszała szlachta kijowska w instrukcji na sejm, Archiv, cz. 2, t. II, s. 111. 
którzy utracili dobra na skutek fałszerstw. Nie zostało jednak przeprowadzone rozgraniczenie ziem województwa. Kijowianie w instrukcji na sejm z 1662 roku uznali, że z tego powodu „wielkie commodum w świętey sprawiedliwości woiewodztwo nasze [...] upatruie”, i domagali się, „aby to ad effectum przyszło”. Podobnie zwracali uwagę na konieczność rozpatrzenia odłożonych spraw w trybunale, ,aby, more antiguo, z inszemi woiewodztwy [...] sądziły się" 14 .

Te postulaty znalazły oddźwięk podczas sejmu, który uchwalił konstytucję „Restytucya dobr Woiewodztw, Kiiowskiego, Bracławskiego, Podolskiego, Czerniechowskiego"15. Jakkolwiek sytuacja w województwie kijowskim była nadal niespokojna, udało się chwilowo przywrócić funkcjonowanie grodu w Żytomierzu, czego potwierdzeniem jest prowadzenie księgi grodzkiej, która zawiera wpisy z lat 1664-1666.

W tym czasie największym utrudnieniem dla funkcjonowania sądów było pozostanie Kijowa w rękach moskiewskich. W instrukcji na sejm z 16 października 1664 roku zebrani na sejmiku ubolewali: ,[...] że dotąd województwo nasze do uspokojenia gruntownego przyść nie może, albowiem sama metropolis w ręku zostaje, Kijów, nieprzyjacielskich. Zaczym i my żadnych sądów mieć nie możem, skąd wielka krzywda być musi iniuratis" ${ }^{16}$. W związku z tym postulowali, aby do czasu wyzwolenia stolicy województwa urzędnicy grodzcy kijowscy odprawiali dwie kadencje sądów w Żytomierzu i dwie w Owruczu. Kijowianie domagali się również skasowania konstytucji z 1659 roku o konserwatach województwa, proponując, aby „sądzone more antiquo byli”. Postulat dotyczący odprawiania sądów znalazł się też w instrukcji na kolejny sejm. Zwrócili wówczas uwagę, że podczas wygnania nie mieli gdzie odbywać swoich sądów. Posłowie mieli się więc starać o wyznaczenie „miejsc sądom grodzkim, na których wszystkie sprawy non obstantibus anterioribus constitutionibus sądzić się będą, per legem" "17, i reasumowanie konstytucji dotyczącej „securitati bonorum et honorum”.

Postulat odbywania sądów w Żytomierzu i w Owruczu został ponowiony w instrukcji na sejm z 28 września 1666 roku oraz następnej, z 7 lutego 1667 roku. Ta druga została uchwalona już po zawarciu traktatu w Andruszowie, ale sejmik odbył się, gdy nie wiedziano jeszcze o tym wydarzeniu. Ponownie podniesiono w instrukcjach znane już argumenty o trudnościach, jakie ponoszą ziemianie z powodu braku miejsca do odbywania sądów ${ }^{18}$. W związku z tym w 1666 roku Kijowianie postulowali, aby urzędnicy grodzcy żytomierscy i owruccy mieli możliwość sprawowania sądów w swych grodach. W następnej zaś domagali się, aby wojewodzie kijowskiemu i jego urzędnikom grodzkim przyznano prawo odprawowania sądów w Żytomierzu i Owruczu do czasu odzyskania stolicy.

\footnotetext{
${ }_{14}$ Archiv, cz. 2, t. II, s. 131.

${ }^{15}$ VL, t. IV, s. 390. Najważniejsze postanowienie dotyczyło zabezpieczenia dóbr ziemskich przed stacjonowaniem w nich wojsk kozackich.

${ }^{16}$ CPAHUK, fond 28, ks. 102, k. 36.

${ }^{17}$ Ibidem. Reasumpcję tej konstytucji i realizację jej postanowień postulowali także Bracławianie w instrukcji na sejm z 24 VII 1668 r., CPAHUK, fond 28, ks. 108, k. 1301v.

18 Archiv, cz. 2, t. II, s. 228.
} 
Sejm w 1667 roku uchwalił konstytucję „Sądy województwa kijowskiego”. Postanowiono, by roczki ziemskie kijowskie odbywały się w Żytomierzu i Owruczu, dopóki Kijów nie będzie zwrócony Rzeczypospolitej (miał pozostać w rękach moskiewskich do kwietnia 1669 r.) Postanowiono też, że wszystkie sądy „powinne mieć rationem spustoszenia tamecznych kraiow"19 oraz uwzględniać zniszczenie części akt i pozostawienie innych w Kijowie. Wygnańcy mieli być sądzeni w trybunale tylko ,in regestro causarum specialium” oraz chronieni od pobierania w kancelariach większych opłat. Jak uzasadniano, nie było to dotychczas przestrzegane i „wielka dzieie się tychże wygnańców depactatio". Konserwaty województwa powinny być sądzone, gdy obywatele odzyskają kontrolę nad swymi posiadłościami (zgodnie z konstytucją z 1659 r.)

Uchwalenie tej konstytucji wywołało zadowolenie ziemian kijowskich, co wyrazili w kolejnej instrukcji ${ }^{20}$. Zawarli w niej nadzieję, że po odzyskaniu Kijowa do miasta zostanie wprowadzona załoga, aby wojewoda mógł rozpocząc tam sądy.

W czasie bezkrólewia po abdykacji Jana Kazimierza wśród kilku przedstawionych egzorbitancji Kijowianie zgłaszali pewne zastrzeżenia dotyczące funkcjonowania sądów grodzkich, na przykład ubolewali, że nie zostały rozpoczęte roczki grodzkie kijowskie ${ }^{21}$. Przypomnieć trzeba, że Moskwa nie zwróciła Kijowa, mimo iż termin upłynął w kwietniu 1669 roku.

Pewne kwestie dotyczące egzulantów znalazły się w konstytucji z 1670 roku. Jakkolwiek celem wprowadzonych wówczas zmian było usprawnienie funkcjonowania trybunału, a nie tylko potrzeby szlachty kijowskiej, to one również zostały uwzględnione. W czasie przeznaczonym dla województwa kijowskiego miały zostać sądzone konserwaty. Dopóki zaś jego obywatele nie odzyskają swoich dóbr, dotąd pierwszy tydzień miał być przeznaczony na rozpatrywane rejestrów specjalnych wszystkich trzech województw ukrainnych ${ }^{22}$.

W latach 1668-1682 ziemianie kijowscy tylko dwukrotnie poruszyli interesujące nas kwestie w instrukcjach. Na początku tego okresu byli zajęci przede wszystkim uzyskaniem reclinatorium za utracone dobra, ponadto sytuacja na Ukrainie Prawobrzeżnej była bardzo niespokojna. Dopiero po szczęśliwym zakończeniu kampanii Jana Sobieskiego w 1671 roku położenie Kijowian poprawiło się. W tym czasie w uchwałach sejmiku znajdujemy postulaty niebędące konsekwencją wygnania, ale zgłaszane czasem przez inne ziemie, na przykład mające wzmocnić rolę

19 „Sądy Woiewództwa Kiiowskiego”, VL, t. IV, s. 439.

${ }^{20}$ Instrukcja kijowskiej szlachty posłom na sejm warszawski, 15 XII 1667 r., Archiv, cz. 2, t. II, s. 249. Postulowali także dokonanie w niej pewnych poprawek mających usprawnić procedury sądowe. Obawy części szlachty dotyczące zwłaszcza sądzenia spraw specjalnych zostały uspokojone w wyniku zdania relacji z sejmu przez posła Marcjana Czaplica jeszcze podczas elekcji deputackiej, CPAHUK, fond 28, ks. 107, k. 622-623v. Wówczas zebrani wcześniej pozytywnie ustosunkowali się do zgłoszonej na ten temat protestacji.

${ }^{21}$ Kwestia ta znalazła się w instrukcji województwa kijowskiego posłom na sejm elekcyjny, 18 III 1669 r., CPAHUK, fond 28, ks. 109, k. $772 \mathrm{v}$.

22 „Ordynacya Trybunału Koron. Lubelskiego”, VL, t. V, s. 32-34. Postanowienia i znaczenie tej konstytucji zob. W. Bednaruk, Trybunat Koronny. Szlachecki sąd najwyższy w latach 1578-1794, Lublin 2008, s. 165-167. 
miejscowych obywateli w sądach. Podczas sejmiku 15 grudnia 1671 roku wyrazili oni nadzieję na szybki powrót do swych dóbr i domagali się, aby „urząd grodzki Zytomirski y Owrucki mieli potestatem odprawowania executyi”. Ponadto oczekiwali, że skoro reasumowane zostały sądy województwa kijowskiego i są ,już bliżey spokojney posessyi [...] aby wszystkie sprawy wojewodztwa, ktore ad feliciora tempora byli prolongowane, w tym miesiącu sądzone byli" ${ }^{23}$. Wydarzenia w ciągu kolejnych pięciu lat wykazały, jak złudne były nadzieje Kijowian na powrót do normalności i swoich posesji. Dopiero po zakończeniu działań wojennych z Portą kwestia ta znalazła się wśród postulatów Kijowian. W grudniu 1676 roku ponownie ubolewali, że "dekreta trybunalskie dla nieoddania Kijowa in executionem przychodzić nie mogą". W związku z tym domagali się, aby posłowie wraz z wojewodą kijowskim wymogli uchwalenie konstytucji, ,aby sądy grodzkie kijowskie w Owruczu sądzone były; na których i sądy skarbowe pomieścić będą mogły"24.

W tym czasie szlachta zgłaszała też różne zastrzeżenia dotyczące funkcjonowania sądów; bolączki dotyczyły przede wszystkim niesumiennego wywiązywania się urzędników (także starostów) ze swoich obowiązków. I tak na przykład starosta owrucki Mikołaj Sapieha złożył przysięgę dopiero podczas sejmiku deputackiego 21 marca 1678 roku, a funkcję starosty pełnił od 1660 roku. Wykonanie przysięgi miało być ważnym krokiem na drodze do przywrócenia funkcjonowania grodu w Owruczu. Jak ponadto zastrzegli obecni: „Ta jednak przysięga per legem et usum województwa naszego introducta nic nie ma derogare authoritati iuridice jw. jm. pana wojewody kijowskiego, generała naszego. Też jednak jm. pan podkomorzy kijowski jako pierwszy urzędnik nasz z jmcią powinien conferre w tej materyjej"25.

Wynika z tego fragmentu uchwały, że szlachta nie wiedziała, jak pogodzić odbywanie sądów w Owruczu przez starostę owruckiego z konstytucją, która przyznawała taką możliwość wojewodzie kijowskiemu. To pogubienie wynikało najpewniej z powodu ciągłych zmian jej położenia i uchwalania praw, których postanowienia nie były wprowadzane w życie.

Wyjątkową decyzję sejmik kijowski podjął 5 marca 1682 roku. Postanowiono wówczas, że retentorzy powinni otrzymywać kondemnaty w grodzie włodzimierskim, „poki sądy nasze kiiowskie nie będą reassumowane" ${ }^{26}$. Zasługuje to na uwagę, ponieważ jeszcze w tym samym roku (laudum sejmiku z 16 grudnia 1682 r.) znajduje się postulat, aby obywatele kijowscy podlegali jedynie sądom w Owruczu i Żytomierzu. Mieli oni domagać się tego na roczkach we Włodzimierzu ${ }^{27}$. Uzasadniano go troską wygnańców, zagrożonych procesami sądowymi, w których musieli oni bronić

${ }^{23}$ Archiv, cz. 2, t. II, s. 307-308.

${ }^{24}$ CPAHUK, fond 28, ks. 118, Instrukcja na sejm posłom województwa kijowskiego, 10 XII 1676 r., k. 482.

${ }^{25}$ CPAHUK, fond 28, ks. 121, Laudum sejmiku deputackiego województwa kijowskiego, 21 III 1678 r., k. 1111-1114v. Wówczas także starosta mianował na podstarościego Remigiana Suryna, a na pisarza komornika granicznego Stefana Wyszpolskiego, „,którzy pomienieni panowie in praesentia tychże urzędników iurament wykonali”.

${ }^{26}$ Archiv, cz. 3, t. II: Акты о козаках (1679-1716 r.), Киев 1868, s. 6-12 (cyt. fragment na s. 8). Na rolę tego sejmiku zwróciłem uwagę w artykule Problemy szlachty kijowskiej..., s. 55.

${ }^{27}$ Laudum sejmiku kijowskiego, 16 XII 1682 r., Archiv, cz. 2, t. II, s. 439-442. 
swoich posiadłości w sądach poza siedzibą województwa. Kilkakrotnie szlachta województwa kijowskiego (podobnie jak innych ukrainnych) zwracała uwagę na niedogodności egzulantów związane z faktem, że są oni pociągani do sądów, którym nie powinni podlegać. Widzimy więc troskę o współobywateli, ale kiedy wspólnota ponosiła straty, bo wybieranie podatków wymagało skutecznych rozstrzygnięć, a sądy w województwie nie działały, Kijowianie zgodzili się, aby gród włodzimierski sprawował sądownictwo w sprawach podatkowych.

Dokumentem przełomowym okazała się konstytucja z 1683 roku. Została uchwalona, kiedy „Woiewodztwo Kiiowskie przyszło do possessyi dobr swoich po tey stronie Dniepru będących"28. Ponieważ Kijów pozostawał w rękach moskiewskich, przewidywała, że urzędnicy sądowi grodzcy kijowscy mieli sądzić roczki grodzkie w Owruczu i Żytomierzu, i ten porządek miał być utrzymany po odzyskaniu miasta. Wówczas według alternaty pierwsza kadencja ma się odbywać w Kijowie, druga w Owruczu, a trzecia w Żytomierzu ,expediantur dla wygody szlachty daleko mieszkających”. Urzędom grodzkim w Owruczu i Żytomierzu, „iż nie mają sądów swoich, tylko susceptę grodową”, przyznano możliwość odprawowania egzekucji „równo z Officyalistami Grodzkiemi Kiiowskiemi”. Uchwalenie tej konstytucji oznaczało faktyczne wprowadzenie zmian w systemie sądownictwa w województwie kijowskim, ponieważ postanowienia z 1659 roku pozostawały do tej pory niezrealizowane.

Podczas sejmiku relacyjnego 24 maja 1683 roku urzędnicy grodzcy kijowscy złożyli przysięgę. Kijowianie liczyli więc na szybkie rozpoczęcie roczków w Owruczu, podczas których „delati ichm. panowie egzaktorowie podawać będą powinni”. Było to dla nich aż tak ważne, że gdyby sądy nie mogły się tam odbyć „delati w trybunale, a to w Włodzimirzu super retentoribus podawać będą powinni i według prawa opisanego kondemnaty cum triplici pensione otrzymywać" ${ }^{29}$. Stanowisko szlachty jest trochę zaskakujące, jak bowiem wspomniano powyżej, Kijowianie starali się, aby obywatele województwa stawali jedynie przed sądami kijowskimi. Roczków wówczas nie zaczęto, brak także informacji wskazujących, że podjęto jakieś przygotowania w tym celu. Może też uniemożliwiła je śmierć wojewody kijowskiego Stefana Niemirycza na początku 1684 roku.

Pewne usprawnienie funkcjonowania sądów województwa nastąpiło, kiedy wojewodą kijowskim został Marcin Kątski, który 15 lipca 1684 roku wydał uniwersał do obywateli województwa. Zawiadamiał w nim o złożeniu roczków grodzkich kijowskich i powołaniu do nich urzędników.

Iż odebrawszy [...] krzesło wojewodztwa kijowskiego i urząd generalski, a chcąc prawu pospolitemu i konstitucyjej na blisko przeszłym sejmie warszawskim, per ordines Regni postanowionej, dosyć uczynić i Świętą sprawiedliwość jako najprędzej przez tak długi czas wakującą

28 „Integritas Woiewództwa Kiiowskiego”, VL, t. V, s. 327.

${ }^{29}$ CPAHUK, fond 28, ks. 128, k. 1182-1184. Pisarz grodzki Tomasz Hulanicki złożył przysięgę podczas elekcji deputata 13 IX, ibidem, k. 708-708v. Byli obecni m.in. podwojewodzi Wacław Stoiński i sędzia grodzki Remigian Suryn. 
ad effectum sine mora przywieźć, sądów kandencyjej pierwszą roczków kijowskich w mieście JKMci Owruczym iuxta obloquentiam constitutionis eiusdem pro die 28 IX anni praesentis składam $^{30}$.

Urzędnikami grodzkimi, którzy otrzymali władzę sądzenia roczków kijowskich, zostali: podczaszy wiłkomirski Dymitr Zabokrzycki, podwojewodzi, podczaszy nowogrodzki Wacław Zubczewski, sędzia, i Tomasz Hulanicki, pisarz. Na czele sądu w województwie stał wojewoda, a nie, jak w większości innych województw, starosta, stąd urzędnikiem grodzkim był podwojewodzi, a nie podstarości. Obowiązywała zresztą zasada nierozdzielności urzędu wojewody i starosty. Miesiąc później Kątski zwołał na 12 września 1684 roku (dzień po elekcji deputata) sejmik elekcyjny sędziego kijowskiego ${ }^{31}$.

Dnia 12 września 1684 roku odbyły się dwa sejmiki ${ }^{32}$. Podczas elekcji sędziego przysięgę złożyli urzędnicy grodzcy kijowscy ${ }^{33}$. Tego aktu dokonali też starosta owrucki Franciszek Potocki oraz powołani przez niego urzędnicy owruccy: Michał Stawecki, podstarości, i Andrzej Długopolski, pisarz ${ }^{34}$. W laudum drugiego zgromadzenia zebrani wyrazili zadowolenie z powodu uchwalenia na sejmie konstytucji, która przywróciła poprawne funkcjonowanie sprawiedliwości po długim, blisko czterdziestoletnim okresie poważnych trudności oraz działań wojewody, który powołał urzędników grodzkich. Poprosili tych urzędników, aby dokonali zmiany terminu roczków, odraczając je do 5 października, oraz starostę owruckiego „dla otwarcia actorum i suscepty panów urzędników swoich z pieczęcią swoją grodzką, aby zesłał do Owrucza wcześnie”"35. Jak uzasadniono, było to spowodowane „częścią dla teraźniejszych sejmików naszych, a barziej dla wakującego grodu owruckiego i zawartych ksiąg", ponieważ nowy starosta owrucki dopiero tego dnia wykonał przysięgę.

Następnego dnia został wydany uniwersał urzędników grodzkich kijowskich.

Iż lubo wyszli innotescencyje [...] naznaczając kadencyją roczków grodzkich kijowskich, pro die 28 praesentis w mieście JKMci Owruczym. Jednak iż starostwo ad praesens owruckie dla niewykonanego przez jm. pana starostę na starostwo juramentu vacabat suscepta cessaverat. Tedy my adhaerendo affectationi ichm. panów obywatelów województwa kijowskiego na sejmik, pro die 11 praesentis, electionis deputatów do Włodzimierza zgromadzonych się i sejmik ekstraordynaryjny po zerwanej elekcyjej kończących, aby się ichmciom w susceptowaniu relacyi wygodziło, po wykonanym przez wielmożnego jm. pana Franciszka Potockiego

${ }^{30}$ CPAHUK, fond 15 , ks. 3, Uniwersał wojewody kijowskiego o roczkach, k. 612v-613v. Uniwersał ten został oblatowany 2 IX 1684 r. M. Kątski został wojewodą 3 VI 1684 r., a nie jak podano w spisach urzędników 1 VIII, Urzędnicy województw..., nr 413, stąd nie można zakwestionować tej daty.

${ }^{31}$ Uniwersał został wydany 12 VIII 1684 r. we Lwowie, CPAHUK, fond 15, ks. 3, k. 599v-600, i oblatowany w grodzie w Owruczu 28 VIII. Jak w oblacie zapisano, ,cum manifestatione na gród żytomierski, ponieważ i do tego czasu po inkursyjach różnych nieprzyjacielskich jeszcze zostaje zawarty i żadnych spraw w nim nie przyjmują, dla wpisania do ksiąg owruckich". Urzędnicy województw..., s. 7.

${ }^{32}$ CPAHUK, fond 28, ks. 129, Elekcja kandydatów na sędziostwo ziemskie kijowskie, k. 1093-1094; ibidem, Laudum województwa kijowskiego, k. 1098-1102v.

33 Juramenty te znajdują się w księdze 129, k. 1090v-1092, 1093-1094 i 1094v-1095.

${ }^{34}$ Ibidem, k. 1095v-1096 i 1096v-1097.

${ }^{35}$ Ibidem, k. 1101. 
na starostwo owruckie juramentu i ichm. panów officyjalistów owruckich super officia, termin ten wyż mianowanej kadencyjej do dnia 5 octobris prorogujemy i odkładamy ${ }^{36}$.

Okazało się jednak, że rozpoczęcie roczków nie nastąpiło zgodnie z planowanymi działaniami, o czym świadczy kilka manifestacji, które zostały oblatowane w księdze owruckiej 5 października. Łowczyna kijowska Krystyna Kowalewska (w imieniu także swego męża) oczekiwała do zachodu słońca na zjechanie urzędników grodzkich w celu rozpoczęcie kadencji.

Aliści ichm. panowie sądowi grodzcy kijowscy sami na termin prefigowany, w innotescencyjach swoich naznaczony nie zjechali i actu kadencyjej nie zapisali, tylko in levipendium praemissorum omnium mimo prawo kazali tylko regentowi swemu grodzkiemu kijowskiemu i woźnemu na miejscu niezwyczajnym, przy klasztorze oo. Jezuitów kolegium owruckiego na rogu, nie na miejscu tym, gdzie się sądy zwykli sądzić ani bywszy u ichm. officyjalistów grodu tutecznego owruckiego i onym się nie opowiedziawszy, którzy praesentes bywszy panowie officyjalistowie $\mathrm{w}$ grodzie tutejszym $\mathrm{z}$ innemi pany obywatelami kijowskiemi, którzy seorsivam manifestandum, także o niezjachanie na sądy ichm. panów sądowych grodzkich kijowskich, przeciwko onym uczynili i actu nie zapisawszy jako należy, tylko przez woźnego sądy przywołać kazawszy już po zachodzie dobrze aż z mrokiem ${ }^{37}$.

Warto zwrócić uwagę na tę manifestację, ponieważ Kowalewscy byli zobowiązani stawić się przed sądem grodzkim właśnie 5 października na instancję delatora Prokopa Kalińskiego, a przedmiotem sporu była majętność Kateńszczyzna ${ }^{38}$. Kowalewska przyjechała do Owrucza, ale roczki zaczęły się z dwudniowym opóźnieniem ${ }^{39}$.

Pod inną manifestacją podpisało się dziewięciu obywateli, wśród których był pisarz grodzki żytomierski Jerzy Rodkiewicz. Podkreślili oni, że konieczność odbywania sądów wynika z obowiązku przestrzegania prawa, czyli uchwalonej konstytucji oraz uniwersału Kątskiego, ale też z troski o interesy obywateli, którzy wiele spraw złożyli w grodzie. Informacje znajdujące się w dokumencie potwierdzają i uzupełniają te podane przez Kowalewską.

A że przerzeczeni ichm. panowie sądowi grodzcy kijowscy in hoc termino przypadłej kadencyjej non companierunt et ullam notitiam o sądach i bytności swej nie dali. A co większa in levipendium praemissorum omnium jm. pan Dydkowski regent grodzki kijowski nie bywszy u ichm. panów officyjalistów grodzkich owruckich, którzy praesentes bywszy na zamku $\mathrm{z}$ ichm. manifestantami ausus est, nie na tym miejscu, gdzie się zwykły, sądy odprawować. Wziąwszy woźnego mimo prawo na ulicy kazał woźnemu akt kadencyjej pomienionej przywoływać. Tedy ichm. manifestantes praecavendo indemnitati suae i całego województwa braci in quantumby ichm. praeiudiciose et non servatis iurius gradibus chcieli sądy swoje zaczynać i zaczynali de nullitate et invaliditate onych ${ }^{40}$.

\footnotetext{
${ }^{36}$ Uniwersał został oblatowany 18 IX, CPAHUK, fond 15, ks. 3, k. 629-630.

${ }^{37}$ Manifestacja Kowalewskiej w sprawie sądów, ibidem, k. 704-705.

${ }^{38}$ CPAHUK, fond 2, ks. 3, Pozwy Kowalewskim, k. 54v-56v.

39 Pierwszy wyrok w księdze pochodzi z 7 X, ibidem, k. 1.

${ }^{40}$ Ibidem, Manifestacja obywatelów województwa kijowskiego przeciwko panom urzędnikom sądowym grodzkim kijowskim, k. 705v-706v.
} 
Protestację przeciwko mianowaniu Zabokrzyckiego podwojewodzim przedstawił natomiast Teodor Niemirycz. Zarzucił mu, że nie posiada osiadłości w powiatach owruckim i żytomirskim (nie ma też na dobrach żony zapisanego dożywocia) i z tego powodu nie powinien podejmować się obowiązków w grodzie. Zarzucił mu także infamię. Ponadto, jak wskazał protestujący, Zabokrzycki z sędzią grodzkim Zubczewskim bezprawnie (bo sądy się nie rozpoczęły) podjęli egzekucję w dobrach łowczego owruckiego Jana Wojnarowskiego. Niemirycz zarzucił mu także niedopełnienie obowiązków, przywołując wspomnianą manifestację grupy szlachty z Rodkiewiczem, „ratione niezjechania na kadencyją przypadającą"

Szlachta miała także inne zastrzeżenia dotyczące działań urzędników sądowych, które zostały podniesione w następnym laudum.

Accedit i to do porządku województwa naszego, iż panowie urzędnicy grodzcy kijowscy mając sobie per constitutionem novellam pozwolone sądy alternatim raz w Owruczu, drugi raz w Żytomirzu po odsądzeniu roczków ksiąg swoich nie zawierają indiminutionem authoritatis ichm. panów starostów żytomirskiego i owruckiego. Aby tedy odtąd w niedziel dwie po skończeniu sądów swoich księgi zawierali po wydaniu dekretów ${ }^{42}$.

W czasie tego sejmiku przysięgę złożył starosta żytomierski Prokop Jan Granowski wraz z urzędnikami swymi, podstarościm Jerzym Rodkiewiczem i pisarzem grodzkim Stefanem Skuratowskim. Dawało to nadzieję obecnym, że sąd w Żytomierzu będzie funkcjonował. Nie dysponujemy jednak żadnymi źródłami, na podstawie których można potwierdzić, że udało się to zrealizować.

Kątski i Potocki pozostali starostami do końca wygnania. Nie zawsze mieli jednak możliwości (zwłaszcza pełniący inne czasochłonne obowiązki Kątski) zajmowania się sądami i nadzorowania podległych sobie urzędników grodzkich. Ci czasem pamiętali o swoich powinnościach. Istniały także obiektywne trudności, które utrudniały działanie sądów. Świadczą o tym także listy innotescencyjne z lat 1687 i 1688 wydawane przez urzędników grodzkich kijowskich. W pierwszym z nich, z 20 października 1687 roku, poinformowano szlachtę, że roczki rozpoczną się 13 listopada, ale w Owruczu, a nie w Żytomierzu, gdzie wypada ich kadencja ${ }^{43}$. Powodem była niespokojna sytuacja w pobliżu tego miasta. W kolejnych zawiadamiano szlachtę o rozpoczęciu roczków sądowych w Owruczu lub o ich odłożeniu. Listy te były oblatowane w księgach grodzkich owruckich lub kijowskich, co logiczne, były bowiem przeznaczone dla szlachty województwa kijowskiego. Nie publikowano ich jednak w grodzie włodzimierskim.

\footnotetext{
${ }^{41}$ Ibidem, k. 706v-707v.

42 CPAHUK, fond 28, ks. 130, Laudum województwa kijowskiego, 5 I 1685 r., k. 650v-653 (cytowany fragment k. $652 \mathrm{v}$ ).

${ }_{43}$ CPAHUK, fond 15, ks. 5, k. 380-381, toż Archiv, cz. 3, t. II, s. 170-171. W kolejnym liście z 4 XI poinformowano szlachtę o odłożeniu roczków do $27 \mathrm{XI}$ z powodu przechodów wojskowych. W następnym roku uniwersał został wydany 20 VII z informacją o początku kadencji 19 VIII 1688 r., CPAHUK, fond 2, ks. 4, k. 67-68, 120-120v. Wiadomo jeszcze o uniwersale obwieszczającym rozpoczęcie roczków z 13 X 1695 r., CPAHUK, fond 15, ks. 9, k. 517v-518v.
} 
Ogólnie szlachta wyrażała krytyczne opinie na temat wywiązywania się urzędników grodzkich ze swych obowiązków. W instrukcji na sejm z 9 stycznia 1688 roku postulowała, aby posłowie upraszali wojewodę kijowskiego o interwencję u urzędników, celem skłonienia ich do odbywania roczków grodzkich, ponieważ „tylko raz przez te lata sądziły się roczki”. Zwrócili uwagę, że przerwy w sprawowaniu sądów w grodach zmuszają szlachtę do kierowania drobnych spraw do trybunału, przez co ludzie ubodzy są narażani na duże koszty ${ }^{44}$. W 1694 roku wszystkie sejmiki ukrainne postulowały reasumpcję praw o sądach grodzkich owruckich i żytomierskich, domagając się, aby były sprawowane w stolicach powiatów. Jak uzasadniła szlachta kijowska: „dla wygody braciej na pustyniach w odległości rezydujących”45. W księgach grodzkich owruckich z czasów wygnania, których zachowało się dziesięć, sprawy dekretowe znajdujemy jedynie w dwu. Z kolei w księgach grodzkich kijowskich w tym czasie również w dwu znajdują się dekrety. Informacja ta może być jedynie sugestią, że roczki odbywały się rzadko, natomiast nie można wyciągnąć z niej jednoznacznego wniosku. Dekrety mogły potem zostać zniszczone lub zaginąć zanim księgi zostały zszyte i znalazły się w archiwum ${ }^{46}$.

Szlachta w całej Rzeczypospolitej wykazywała troskę o los budynków, w których odbywały się sądy. Kijowianie, mając obietnicę otrzymania odszkodowania za utracone w Traktacie Grzymułtowskiego dobra, przeznaczyli z nich na ten cel $1000 \mathrm{zt}^{47}$.

Konstytucja sejmu koronacyjnego z 1697 roku reasumowała postanowienia z 1659 roku o nienaruszalności dóbr ziemskich oraz o sądach ${ }^{48}$. Był to krok w kierunku przywrócenia sądu w Żytomierzu, chociaż sytuacja na Ukrainie stawała się coraz bardziej niespokojna.

W 1701 roku rozpoczęto prowadzenie nowej księgi żytomierskiej. W niej znajdują się przysięgi, które 14 września złożyli nowi urzędnicy grodzcy: podczaszy żytomierski Kazimierz Stanisław Stecki na urząd podstarościego, miecznik żytomierski Jan Suryn - sędziego - i horodniczy kijowski Maciej Stefan Skuratowski - pisarza grodzkiego ${ }^{49}$. Zostali oni powołani przez nowego starostę Józefa Tomasza Karczewskiego, a przysięgi złożyli w obecności licznie zebranej szlachty. Wkrótce potem, w instrukcji danej posłom na sejm z 10 listopada 1701 roku, szlachta postulowała, aby „konstitucyja o sądach ichm. panów starostów żytomirskiego i owruckiego" 50 została reasumowana i nastąpiło zapowiedziane w 1659 roku rozgraniczenie powiatów województwa oraz powołano do niego komisarzów. Postulat ten jest potwierdzeniem,

${ }^{44}$ CPAHUK, fond 28, ks. 133, Instrukcja posłom województwa kijowskiego, k. 798v.

${ }^{45}$ CPAHUK, fond 28, ks. 139, Instrukcja województwa kijowskiego, 1 XII 1694 r., k. 907v; ibidem, Instrukcja województwa bracławskiego, 1 XII 1694 r., k. 914v; ibidem, Instrukcja województwa czernihowskiego, 22 XII 1694 r., k. 930.

${ }^{46}$ Dekrety znajdują się w księdze owruckiej nr 2 (obejmującej lata 1681-1682) i 3 (1683-1684) oraz w księdze kijowskiej 3 (1684-1685) i 7 (z 1696 r.).

${ }^{47}$ CPAHUK, fond 28, ks. 134, Laudum województwa kijowskiego, 11 VI 1689 r., k. 1081.

${ }^{48}$ Reces Seymu Coronationis, VL, t. VI, s. 13.

${ }^{49}$ CPAHUK, fond 11, ks. 16, k. 1-3. Przysięgi te oblatowano 14 IX $1701 \mathrm{r}$.

${ }^{50}$ Ibidem, Instrukcja posłom na sejm walny warszawski, k. 33-40v (cyt. fragment k. 37). 
że kwestie dotyczące sądów województwa kijowskiego musiały czekać na rozwiązanie do czasów po powrocie szlachty do swych siedzib na Kijowszczyźnie.

W początkowym okresie powstania szlachta kijowska starała się o usprawnienie działań sądów. Potem w latach 1652-1659 jej położenie na tyle się pogorszyło, że nie podejmowała żadnych inicjatyw w tej sferze. Po pojawieniu się możliwości odzyskania przynajmniej części posiadłości w 1659 roku została uchwalona konstytucja powołująca sądy grodzkie w Owruczu i Żytomierzu. Ponieważ Rzeczypospolitej nie udało się odzyskać Kijowa, celem szlachty było przeprowadzenie zmian w organizacji sądownictwa w województwie. Z powodu utrzymujących się napięć na Ukrainie długo jednak nie udało się tych zamysłów zrealizować i utworzyć nowych sądów. Doszło do tego dopiero w 1683 roku, chociaż o pełnym zrealizowaniu wcześniejszych postulatów Kijowian można mówić dopiero na początku XVIII wieku, kiedy przywrócono funkcjonowanie grodu w Żytomierzu.

\section{BIBLIOGRAFIA}

\section{Źródła rękopiśmienne}

Центральний державний історичний архів України, Київ [Centralne Państwowe Archiwum Historyczne Ukrainy w Kijowie (CPAHUK)]

Fond 2 (Księgi grodzkie kijowskie), ks. 3, 4

Fond 11 (Księgi grodzkie żytomierskie), ks. 13, 16

Fond 15 (Księgi grodzkie owruckie), ks. 3, 5, 9

Fond 28 (Księgi grodzkie włodzimierskie), ks. 102, 108, 109, 118, 121, 129, 130, 133, 134,139

\section{Źródła drukowane}

Архив Юго-западной России, издаваемый временной комиссией для разбора древних актов, состоящей при Киевском, Подольском и Вольнском генерал-губернаторе, cz. 2, t. I: Постановления дворянских провинщиальных сеймов, в Югозападной России, Киев 1861; cz. 2, t. II: Акты для истории провинцииальных сеймиков Юго-Западного края во второй половине XVII века, Киев 1888; cz. 3, t. II, Акты о козаках (1679-1716 r.), Киев 1868; cz. 3, t. IV, Акты относящиеся к эпохе Богдана Хмельниикаго, Киев 1914.

Urzędnicy województw kijowskiego i czernihowskiego XV-XVIII wieku. Spisy, oprac. E. Janas, W. Kłaczewski, Kórnik 2002.

Volumina Legum, Warszawa 1980, t. II, IV-VI. 


\section{Opracowania}

Bednaruk W., Sejmiki deputackie województw południowo-wschodnich Rzeczypospolitej od XVI do XVIII wieku [w:] Wielokulturowość polskiego pogranicza. Ludzie, idee, prawo. Materiały ze Zjazdu Katedr Historycznoprawnych, Augustów, 15-18 września 2002, red. A. Lityński, P. Fiedorczyk, Białystok 2003, s. 259-267.

Bednaruk W., Trybunat Koronny. Szlachecki sąd najwyższy w latach 1578-1794, Lublin 2008.

Крикун М., Повітовий поділ Київського воєводства в останній третині XVI-XVIII cm. [w:] Історико-географічні дослідження на Україні. Збірник наукових праць, Киев 1992, с. 68-84.

Maisel W., Trybunat Koronny w świetle laudów sejmikowych i konstytucji sejmowych, „Czasopismo Prawno-Historyczne” 1982, t. XXXIV, z. 2, s. 73-109.

Ochmann-Staniszewska S., Uwagi o politycznej roli Trybunału Koronnego w XVII w. [w:] Między Wschodem a Zachodem. Rzeczpospolita XVI-XVIII w., Warszawa 1993, s. $103-110$.

Rachuba A., Wielkie Księstwo Litewskie w systemie parlamentarnym Rzeczypospolitej w latach 1569-1763, Warszawa 2002.

Stolicki J., Problemy szlachty kijowskiej w drugiej połowie XVII w. [w:] Studia i materiaty z historii nowożytnej i najnowszej Europy Srodkowo-Wschodniej, t. 1: Na styku epok. Ziemie poludniowo-wschodniej Rzeczypospolitej od XVII do poczatku XIX wieku, red. T. Kargol, W. Michałowski, Kraków-Kijów 2020, s. 49-68. 